\title{
WALKING ON BROKEN GLASS Gender as predictor of job precariousness among young people in Spain
}

\author{
Juan Carlos Solano Lucas
}

Departamento de Sociología, Universidad de Murcia, Spain

Marcos Bote Díaz

Departamento de Sociología, Universidad de Murcia, Spain

Juan Antonio Clemente Soler

Departamento de Sociología, Universidad de Murcia, Spain

José Ángel Martínez López

Departamento de Trabajo Social, Universidad de Murcia, Spain

Lola Frutos Balibrea

Departamento de Sociología, Universidad de Murcia, Spain

\begin{abstract}
Previous evidence reveals that socioeconomic factors, such as contract duration, occupation, activity sector age, training, nationality, marital status or gender, lead to precariousness. This research looks into the intersectionality of inequalities in order to explain the impact of precariousness among young people based on gender. Data from the Spanish Labor Force Survey (EPA) from 2005 to 2016 has been analyzed using logistic regression and hierarchical segmentation. Results suggest that the economic crisis has widened the gender gap in precarious jobs, such that currently, young women are more likely to face precarious situations as compared to young men.
\end{abstract}

Keywords: precariousness, gender inequality, intersectionality, hierarchical segmentation

Andar sobre vidro quebrado: o género como preditor da precariedade do emprego entre os jovens em Espanha

Resumo Evidências anteriores revelam que fatores socioeconómicos, tais como duração do contrato, ocupação, setor de atividade, idade, formação, nacionalidade, estado civil ou sexo, conduzem à precariedade. Esta investigação analisa a interseccionalidade das desigualdades, a fim de explicar o impacto da precariedade entre os jovens com base no género. Os dados do Inquérito às Forças de Trabalho espanholas (EPA) de 2005 a 2016 foram analisados utilizando a regressão logística e a segmentação hierárquica. Os resultados sugerem que a crise económica alargou o fosso entre os géneros em empregos precários, de tal forma que atualmente as mulheres jovens são mais propensas a enfrentar situações precárias do que os homens jovens.

Palavras-chave: precariedade, desigualdade de género, interseccionalidade, segmentação hierárquica

Marcher sur du verre brisé: le genre comme prédicteur de la précarité de l'emploi chez les jeunes en Espagne

Résumé Des données antérieures révèlent que des facteurs socio-économiques, tels que la durée du contrat, la profession, le secteur d'activité, l'âge, la formation, la nationalité, l'état civil ou le sexe, conduisent à la précarité. Cette recherche s'intéresse à l'intersectionnalité des inégalités afin d'expliquer l'impact de la précarité chez les jeunes en fonction du genre. Les données de l'enquête espagnole sur les forces de travail (EPA) de 2005 à 2016 ont été analysées à l'aide de la régression logistique et de la segmentation hiérarchique. Les résultats suggèrent que la crise économique a élargi l'écart entre les sexes en matière d'emplois précaires, de sorte qu'actuellement, les femmes plus jeunes sont plus susceptibles d'être confrontées à des situations précaires par rapport aux hommes plus jeunes.

Mots-clés: précarité, inégalité entre les genres, intersectionnalité, segmentation hiérarchique 

España

Resumen Evidencia previas revelan que los factores socioeconómicos, como la duración del contrato, la ocupación, el sector de actividad, la edad, la formación, la nacionalidad, el estado civil o el género, conducen a la precariedad. Esta investigación indaga en la interseccionalidad de las desigualdades para explicar el impacto de la precariedad entre los jóvenes en función del género. Se han analizado los datos de la Encuesta de Población Activa (EPA) de España entre 2005 y 2016 mediante regresión logística y segmentación jerárquica. Los resultados sugieren que la crisis económica ha ampliado la brecha de género en los empleos precarios, de manera que actualmente las mujeres jóvenes son más propensas a enfrentarse a situaciones de precariedad en comparación con los hombres jóvenes.

Palabras-clave: precariedad, desigualdad de género, interseccionalidad, segmentación jerárquica

\section{Introduction}

Currently, academic consensus exists regarding the need to analyze changes in the labor market from a global perspective, taking into account the interconnections between economics and politics. Within this perspective, Dahrendorf (2005) reflects the influence of global society on work, especially on women, including the expansion of part-time, temporary, independent work (not totally voluntary) and the different combinations between them. "The accumulation of capital on a global scale begets a global working class in the sense of an accelerated process of proletarianization" (Munck, 2013: 754). In addition, as Kalleberg (2009) points out, the growth of precarious work has also made educational decisions more precarious.

The uncertainty and unpredictability of job opportunities in the future make it difficult for students to avoid precariousness. The precariat appears as an anti-class, a concept that continues to be used in increasing numbers around the world. Throughout the course of this systematic transformation, young people do not have even a minimum job security, regardless of their qualifications (Asçi, 2018).

Since precariousness is a global phenomenon (Standing, 2013), the context in which it takes place is quite influential (Fullerton, Robertson and Dixon, 2011). Differences have been found not only in the global perspective (Mosoetsa, Stillerman and Tilly, 2016), but also within regions. Countries such as Portugal or Spain suffer from a more severe level of precariousness, with Spain being the country with the most involuntary precarious jobs and more vulnerable labor rights in Europe (do Carmo and Matias, 2019; McKay et al., 2012). Recent studies on occupational segregation in Spain suggest that "the affected groups tend to concentrate on occupations and/or activities with lower wages and worse social status, which has social consequences that extend beyond the functioning of the labor market (poverty, social discrimination or excessive dependence on social policies)" (Odriozola and Peña, 2016: 8).

Social origin, human capital, economic policy, and working conditions have led to an increasingly segmented/dual labor market, however, precarious jobs are no 
longer only concentrated in the secondary labor market (Kalleberg, 2009: 5). From an analytical perspective, precarious jobs have major consequences on health, across the southern European countries, since long shifts are required to increase salaries (Artazcoz et al., 2016). Precarious employment, in turn, is considered a key determinant of inequalities in social health (Puig-Barrachina et al., 2014: 144).

The economic crisis has revealed that precariousness is a structural condition, rather than a contingency for youth and women. A recent study found that "of all the groups [...] young Spanish men's workforce participation was hit hardest by the Great Recession, perhaps because they are typically in industries such as construction and tourism [...]. Age rivals gender as a dominant risk factor in recessionary times" (Craig, Churchill and Wong, 2018: 20). The political and economic measures adopted after the economic recession had a severe impact on women, especially regarding the working conditions of women in low skill jobs, the difficulty to achieve life-work balance and the increased wage gap, with more women working in minimum wage jobs (Távora and Rodríguez-Moñono, 2018).

Neoliberal policies have favored the development of flexible work conditioning the salaries and, therefore, the individual's income and spending capacity. As stated by Greer (2016), wage flexibility is an imperative of globalization. This leads to lower contributions of workers and therefore, less social protection of unemployment systems. This increased job insecurity of unemployed people interferes also with mobilization skills. People who are "active unemployed" have even less power to defend their interests than workers who develop precarious jobs. In addition, the connections between unemployment and/or unemployment and job insecurity are increasingly obvious. As a consequence of austerity policies, "the segmentation sets young workers entering (and re-entering) the labour markets on temporary contracts against adult workers on standard contracts, and migrant or foreign workers on temporary work permits against national workers. When a downturn strikes, the groups with the least employment protection are the natural candidates for a buffer role, men and women alike" (Bettio et al., 2012: 50). Besides, the restriction of spending on public policies related to the Welfare State has especially affected women, who have to access the labor market, even if this means doing so within the precariousness, with low wages, or in the informal economy (Girón and Correa, 2016).

Labor flexibility is causing an increasingly larger number of young people to be hired in precarious jobs, but with a higher qualification. These workers access the labor market via the category of underemployment. In the specific case of Spain, "temporary employment can be found, paradoxically, less associated with over-education than permanent employment" and less in relation to what happens in other countries (Ortiz, 2010: 60). In addition, women in Spain have traditionally been linked to job insecurity for several reasons: "(a) lower activity rate; (b) lower general rate of remuneration or higher percentage of workers with low profit (low pay rate); (c) higher percentage of women in occupations linked to the low pay rate; (d) higher percentage of women outside the protection system" (Belzunegui, 2012: 237). On the other hand, a study published by Bernardi and Ares (2017) on the connection between education and the labor market, concludes that social origin is a 
determinant factor for access to the labor market, calling into question the theory of human capital and jeopardizing the idea that "once two individuals achieve the same level of education, they [...] have the same chances of success in the labour market" (op. cit.: 15).

Over recent years, the position of women in the labor market has gradually improved, thanks to improved training and a decrease in the female unemployment rate. However, ongoing segregation by gender in the labor market continues. For instance, "negative shocks affecting employment in male-dominated industries will affect the male unemployment rate more than the female rate [...] The share of women with fixed-term contracts relative to men actually seems to have a negative effect on the gender unemployment gap" (Peña-Boquete, 2014: 298).

No analysis on precarious female labor "would be complete without a consideration of the life course, and the cumulative disadvantages that accrue to women as their household circumstances constrain their employment options to a far greater extent than those for men" (Rubery, Smith and Fagan, 1999: 106). Torns, Recio and Durán (2013) attempt to explain the existing gender inequality in today's society based on the idea of the sexual contract established in the first stage of the capitalist industrial society. According to this argument, the authors consider that "the reasons that explain the persistence of the sexual division of labor must be traced in the alliance of powers between capitalism and the patriarchy that shapes the socioeconomic, political and cultural organization of such societies" (Torns, Recio and Durán 2013: 154). When analyzing female precariousness, the implications of care, both after maternity leave or while caring for other relatives, must be taken into account. Caring can have a negative impact on female labor conditions and professional development, as suggested by past works. For instance, women with lower incomes will return to the labor market sooner (and with poor work conditions) due to pressing economic hardships (Han et al., 2008). In addition, "human capital and family-related investments function differently for men and women when it comes to precarious employment [...]. Women are more likely to be employed in precarious work settings as a result of employers' discriminatory preferences, as opposed to human capital alone" (Young, 2010: 91).

Although part-time employment does not inexorably lead to precariousness, "[it] plays a role in reproducing gender segregation and marginalising those with household responsibilities which are hard to balance with full-time work" (Adams and Deakin, 2014: 789). Women accept part-time jobs mainly in feminized occupations. In southern European countries such as Spain, there is, therefore, a dual inequality given that accepting part-time work and doing so in low-skilled feminized jobs leads to even more precarious and unequal situations (Alcañiz and Monteiro, 2016). Thus, precarious work is mainly based on "(asymmetrical) employment relations and related employment conditions" (Puig-Barrachina et al., 2014:144). The new labor market segmentation is found within the framework of "changing international patterns and experiences of labour market inequalities in the wider context of shifting gender relations, regulatory regimes and production structures" (Grimshaw, et al., 2017). These patterns of precariousness share a common feature: the difficulty in reversing the process. 


\section{Legal framework}

In this section, the impact of the different labor reforms carried out in Spain will be analyzed. In order to do so, the reforms of labor market legislation passed between 2001 and 2012 will be considered. Legislative reforms in labor matters in Spain were conditioned by economic and, above all, political issues. At the same time, the outbreak of the economic crisis in 2007, the increase in unemployment and the precariousness of the labor market, especially amongst the more vulnerable sectors (youth and women), favored the use of a gender-based perspective in a context of economic crisis (Gálvez and Rodríguez, 2013).

Table 1 Labor market legislation (2001-2012)

\begin{tabular}{|c|c|c|}
\hline Year & Law & Measures \\
\hline 2001 & $\begin{array}{l}\text { Law } 12 / 2001 \text {, of July } 9 \text {, on urgent measures } \\
\text { to reform the labor market to increase } \\
\text { employment and improve its quality }\end{array}$ & $\begin{array}{l}\text { Open-ended contract to promote open-ended hiring. } \\
\text { Disadvantage minorities' (youth, women...) inclusion in } \\
\text { the labor market. } \\
\text { Increase in bonus for hiring unemployed women. }\end{array}$ \\
\hline 2002 & $\begin{array}{l}\text { Royal Decree-Law } 5 / 2002 \text {, of May } 24 \text {, } \\
\text { on urgent measures to reform the system } \\
\text { of unemployment benefits and enhance } \\
\text { employability. }\end{array}$ & $\begin{array}{l}\text { Out-of-court arrangement for unfair dismissal (the } \\
\text { employer does not have to pay court fees). } \\
\text { A cut in unemployment subsides. }\end{array}$ \\
\hline 2006 & $\begin{array}{l}\text { Royal Decree-Law } 5 / 2006 \text {, of June } 9 \text {, } \\
\text { on improving growth and employment. }\end{array}$ & $\begin{array}{l}\text { Training contract for students in training workshops (up } \\
\text { to } 24 \text { years old). } \\
\text { Employment promotion. } \\
\text { Measures to reduce temporary contracts. } \\
\text { Measures to reduce employer's fees. }\end{array}$ \\
\hline 2010 & $\begin{array}{l}\text { Royal Decree-Law } 10 / 2010 \text {, of June } 16 \text {, } \\
\text { on urgent measures to reform the labor } \\
\text { market. }\end{array}$ & $\begin{array}{l}\text { Extraordinary actions to promote orientation and labor } \\
\text { insertion. } \\
\text { Revenue bonus for employers. } \\
\text { Training contract. Internship contracts (increase in } \\
\text { duration). } \\
\text { Plan to reduce temporary contract. } \\
\text { Revenue bonus for hiring young. }\end{array}$ \\
\hline 2012 & $\begin{array}{l}\text { Royal Decree-Law } 3 / 2012 \text {, of February } 10 \text {, } \\
\text { on urgent measures to reform the labor } \\
\text { market. }\end{array}$ & $\begin{array}{l}\text { Young unemployed subsides ( } 16-30 \text { years old). } \\
\text { Promotion of training and education (training contracts). }\end{array}$ \\
\hline
\end{tabular}

Law 12/2001, of July 9, on urgent measures to reform the labor market to increase employment and improve its quality, introduced different measures such as the inclusion of new groups, including those in which women were underrepresented. Bonuses for unemployed women between the ages of 16 and 45 years were also extended. And, following the line initiated by Law 39/1999, of November 5, on reconciliation of work and family life, Law 12/2001 extended regulations on maternity and paternity leaves. 
Nonetheless, Gálvez and Rodríguez (2013) point out that, despite legislative advances in terms of equality and reconciliation of professional and personal lives during the 1990s and 2000s, these measures were insufficient, given the slowness of their implementation or their elimination with austerity policies.

The reform undertaken in 2001 did not receive the consensus of social stakeholders, since the signing of the governmental reform in May 2002 jeopardized certain basic aspects of employment such as dismissal and unemployment benefits (Ortiz, 2013). This reform led to an increase in temporary hiring costs and, instead of stimulating job creation, it was aimed at the promotion of indefinite hiring and the conversion of temporary contracts into permanent contracts (Alonso-Borrego and Galdón, 2007).

Royal Decree-Law 5/2006, of June 9, on improving growth and employment, was the next labor reform undertaken by the Government. Although this reform was initiated during a situation of job growth, problems remained in the labor market that had to be overcome in order to fulfil the commitments of the Lisbon Strategy. Among the problems targeted by this law there is the low occupation and activity rate of Spanish women and the unemployment rate, which remains higher than the European Union average and is especially high for women, young people and the disabled. Among the reforms introduced in 2006, the article concerning bonuses for the maintenance of employment and equal opportunities established that "indefinite employment contracts for female workers who are suspended for maternity or who leave due to child care, with the effective return of women to work in the two years following the date of the onset of maternity leave and provided that this incorporation takes place as of July 1, 2006, will be entitled to a monthly bonus of the employer's Social Security contribution or, as the case may be, for its daily equivalent per hired worker, of 100 euros per month $(1,200 \mathrm{eu}-$ ros/year) during the four years following the effective reincorporation of the woman to work.

In general, almost all of the labor legislative amendments introduced in the area of gender are inspired by bonuses or permits in cases of maternity or breastfeeding, facilitating the incorporation of young women into the labor market, as well as measures to ensure certain job stability in cases of maternity and, ultimately, the reconciliation of work and family life. In this sense, as Cebrián and Moreno (2007) stated, changes in production processes, in the labor market or in protection systems are macro factors that impact how individuals combine work with their family life. In short, child care continues to be and will be an increasing barrier to the employment of women (Gálvez and Rodríguez, 2013).

It is important to consider Organic Law 3/2007, of March 22, for effective equality between women and men, which consolidated previous advances, increasing the right of parents with minor children and introducing greater flexibility in the working hours of parents with children under the age of 5 (Gálvez and Rodríguez, 2013). The so-called "Law of Equality", introduced remarkable improvements in gender equality, both in political matters and in social or labor issues. It introduced innovations such as the improvement of maternity benefits and 
the granting of maternity leave to women under 21 , unemployed women and those who do not meet the minimum time required to access the benefit (Lombardo and León, 2014).

The political aim of gender equality requires not only specific policies but also the application of the principle of transversality by which all laws, policies and public budgets must take into account the objective of equality and analyze its impact both ex ante and ex post, from education to taxation (Gálvez and Rodríguez, 2013).

Following these innovative regulatory reforms on labor issues, the outbreak of the economic crisis in 2007 dynamited the labor market, causing a large increase in unemployment in Spain, and the implementation of the so-called "austerity policies". According to Lombardo and León (2014: 25), the regression in equality policies due to "austerity" policies and the prioritization of economic objectives over social ones were evident at a European level. This crisis was created within an economic model that generated inequalities, a phenomenon that is not alien to the outbreak and evolution of the crisis (Torres and Gálvez, 2010).

In this situation of economic and social crisis, Royal Decree-Law 10/2010, of June 16, on urgent measures to reform the labor market was passed, introducing measures to promote vocational training, training contracts and or bonuses for the indefinite hiring of young people. The 2010 reform introduced bonus payments for indefinite hiring. Companies were offered bonuses for the hiring of unemployed individuals between the ages of 16 and 30 having special employability problems (those registered as unemployed for at least 12 months in the State Public Employment Service). It included a special provision for young females (aged 16-30), increasing this bonus from 800 to 1,000 euros.

The last reform passed to date was Royal Decree-Law 3/2012, of February 10, on urgent measures to reform the labor market. This labor reform introduced new features that reversed all the achievements obtained in terms of equality in the labor market. According to Ballester (2012), the reduction of parental rights as a consequence of the 2012 labor reform could have the effect of expelling those who fail to reconciliate their various responsibilities from the labor market.

Although measures have been introduced to promote the incorporation of women into the labor market, facilitating family and work reconciliation, the latest labor reforms have seemingly dynamited any achievements gained. As Cebrián and Moreno (2007) note, the problem of conciliation is a pending issue for women, and many social and cultural barriers continue to hinder the combination of work and family life.

Taking into account gender differences (figure 1), the unemployment rate reflects the greater vulnerability of women in Spain when facing fluctuations in the labor market, which contrasts sharply with the European scenario in which this indicator converges in a greater way. In the case of Spain, the gender gap increases during periods of job creation. 


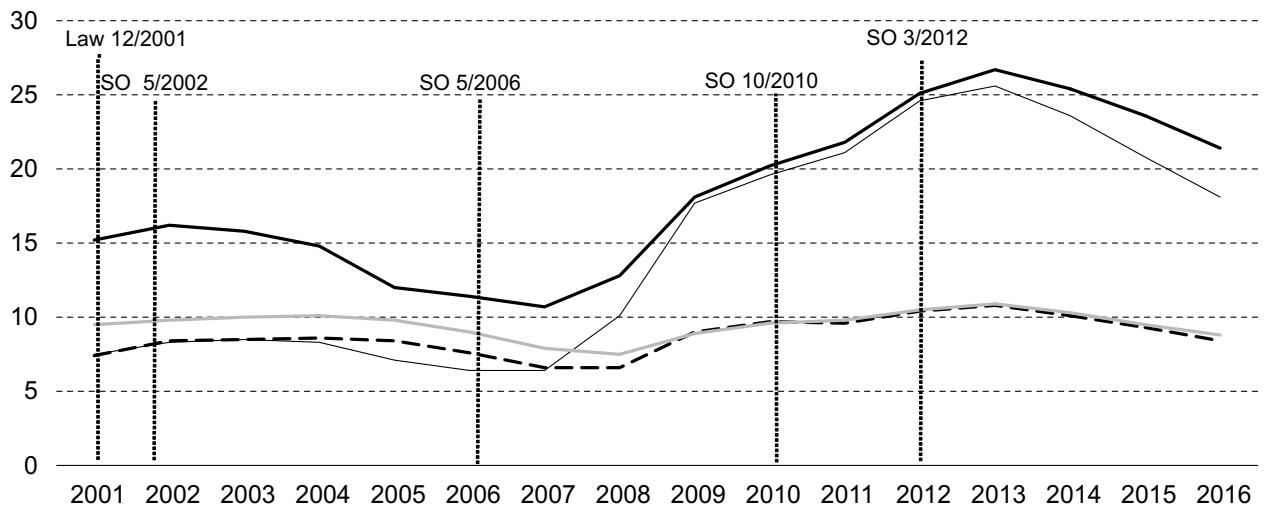

- Male Spain - - Male EU -Female Spain -Female EU

Figure 1 Unemployment rate (European Union-27 and Spain) by gender, 2001-2016

Source: Eurostat — Spanish Labor Force Survey (EPA) 2005-2016

\section{Data and methods}

The main objective of this article is to examine the different impact of precariousness employment based on gender. Our hypothesis states that, together with gender, marital status, age and educational level are the main predictors of precariousness among young people. Young women without qualifications are the most likely to face precariousness.

To verify the hypotheses, data from the fourth quarters of the Spanish Labor Force Survey (EPA) between the years 2005 and 2016 were used, attempting to establish repeated trends in the longitudinal analysis carried out.

First, a descriptive analysis of the Spanish labor market was carried out, considering variables such as unemployment, activity, temporality, contract duration, and type of working day, all mediated by gender, educational level, age groups and social class. Second, after identifying the precarious situation, factors predicting its concurrence were analyzed.

Although the precariousness phenomenon is widespread and has been theorized about since the early 1960s, when discussions on dualization in the labor market began, no official definition of the precarious labor situation exists. However, there are several approaches from an academic perspective. Thus, recent reports from international organizations have considered "working poor" phenomenon (Lohmann, 2009; Spannagel, 2013) and the subject has been approached by academics for over two decades now (Alberio, 2011; Klein and Rones, 1989). In short, this paper embraces the positions that have recently been recognized in the academic realm regarding the operationalization of precariousness to face statistical treatment, linking the concept to the absence of some of the standard employment 
dimensions (Adams and Deakin, 2014; Golsch, 2003). So, the dependent variable is finally calculated as a dichotomous variable, considering precarious contracts to be those that are either opaque, training contracts, discontinuous-fixed or fixed, as well as part-time temporary contracts.

The salary component cannot be taken into account since information was not available in the database. The use of another database would have resulted in the loss of other types of information linked to the workplace itself, as well as participant's sociodemographic information.

Subsequently, the variables to be used as predictors of the precarious situation were established. These variables included age in 5-year groups, gender, marital status, nationality, educational level, lifelong education, activity, occupation, duration of the contract and the difference between agreed weekly hours and actual working hours. For the treatment of the occupation variable, the 11 major categories defined both by Eurostat and the Spanish Labor Force Survey were maintained in the European Socio-Economic Classification. In this sense, occupations were not treated as social classes, since the socioeconomic classification obtained does not reflect social class of origin or family background. For the purpose of this paper, details on occupations are much more explanatory than their division into social classes, especially when considering the broad debate on the relevance of using social class indicators that marginalize cultural and social capital (Erikson et al., 2013; Savage et al., 2015). Finally, to treat educational level, the variable has been categorized into three values, which correspond to the grouping of ISCED categories: 0-2, Low; 3-4, Intermediate; 5-7, Superior.

In order to determine the joint effect of all of the variables in the prediction of the precarious event, first, a binary logistic regression model was adopted. The results were also replicated for the overall population in order to isolate the bias resulting from a lack of labor market experience by young individuals. Second, in order to trace the profiles that best define and predict precariousness, hierarchical segmentation was performed. The most widespread divisive method, CHAID (Chi-Squared Automatic Interaction Detector) was used. Predictor variables were the same as in the binary logistic regression model. In addition, the segmentation divided the sample by gender in order to identify heterogeneous patterns for men and women.

The choice of this technique was based on the fact that hierarchical segmentation has been proven to be very robust for profiling (Kuster-Boluda, et al., 2010) and has been found to be especially useful in labor market analysis (Marrero, Rodríguez and Ramos-Henríquez, 2016). The technique of hierarchical segmentation or decision tree traces dependency between variables. The main aim is to divide a sample into homogeneous blocks, in order to detect those variables that are capable of identifying heterogeneity and whether there is an explanatory and predictive pattern of the dependent variable (Escobar, 2007; Román and Lévy, 2003; Tiwari, Singh and Vimal, 2014). Hierarchical segmentation is one of the divisive methods that, beginning with a global sample of a single group, divides the sample into subgroups until homogeneous subgroups or clusters are formed with a smaller number of subjects. Therefore, the final objective of this technique is to divide the sample such that 
116 Juan C. Solano Lucas, Marcos B. Díaz, Juan A. Clemente Soler, José Á. Martínez López and Lola Frutos Balibrea

Table 2 Operationalization of variables in the Spanish Labor Force Survey (EPA)

\begin{tabular}{ll}
\hline Age & 16-19; 20-24; 25-29. \\
Nationality & Spaniard; foreigner \\
Marital Status & Married; not married \\
Educational level & ISCED 0-2; ISCED 3-4; ISCED 5-8 \\
Training & Training; no training \\
Economic sector & Agriculture; manufacturing; building; service \\
& Large employers, upper management/professionals; lower \\
management/professionals, higher supervisory/technicians; intermediate & occupations; small employers and self-employed (non-agriculture); lower \\
Occupation & sales and service; small employers and self-employed (agriculture); lower \\
& supervisors and technicians; lower technical; routine. \\
Contract hours - working hours & No difference; Up to 10; >11 \\
Contract duration & $<6$ months; $7-18$ months; 19-36 months; >37 months \\
\hline
\end{tabular}

groups with uniform content are formed and, at the same time, those groups are very different between them. As several authors have revealed, this technique proves to be very useful both in its isolated application and as complementary or confirmatory to other analyses (Blanco et al., 2015).

\section{Findings}

During the period, new types of contracts proliferated with characteristics of precariousness, which reduced the proportion of young people who are hired on a permanent basis. In 2005, permanent contracts accounted for $44.7 \%$, with women being slightly more represented (45.9\%) than men (43.8\%). The evolution followed throughout the period analyzed (figure 2) increased until 2012, reaching 58.5\% for both genders, later beginning to decrease until reaching 41.4\% in 2016 (3.3 percentage points lower than in 2005). This phenomenon could be considered to reflect upon the precariousness of the labor market. In the case of discontinuous-fixed contracts, they have hardly changed throughout the studied period, remaining as a residual category of contracting.

As shown in the previous graph, temporary employment has increased for both sexes, beginning at $34.7 \%$ in 2004 for males and $31.1 \%$ for females and reaching $42.4 \%$ and $42.6 \%$, respectively by the end of the period. In the case of training contracts, a slight increase is seen for both men and women.

The so-called "opaque temporary contracts" are those whose fundamental characteristic is that they involve great vulnerability, lacking the basic features in the employer-employee relationship regarding time, aim and scope of tasks and, they tend to be verbal contracts verging on the informal economy, leading to instability and limiting the future careers of young people. These types of contracts have decreased during this period. In fact, in 2005 they affected up to $16.8 \%$ of the young population, slightly 


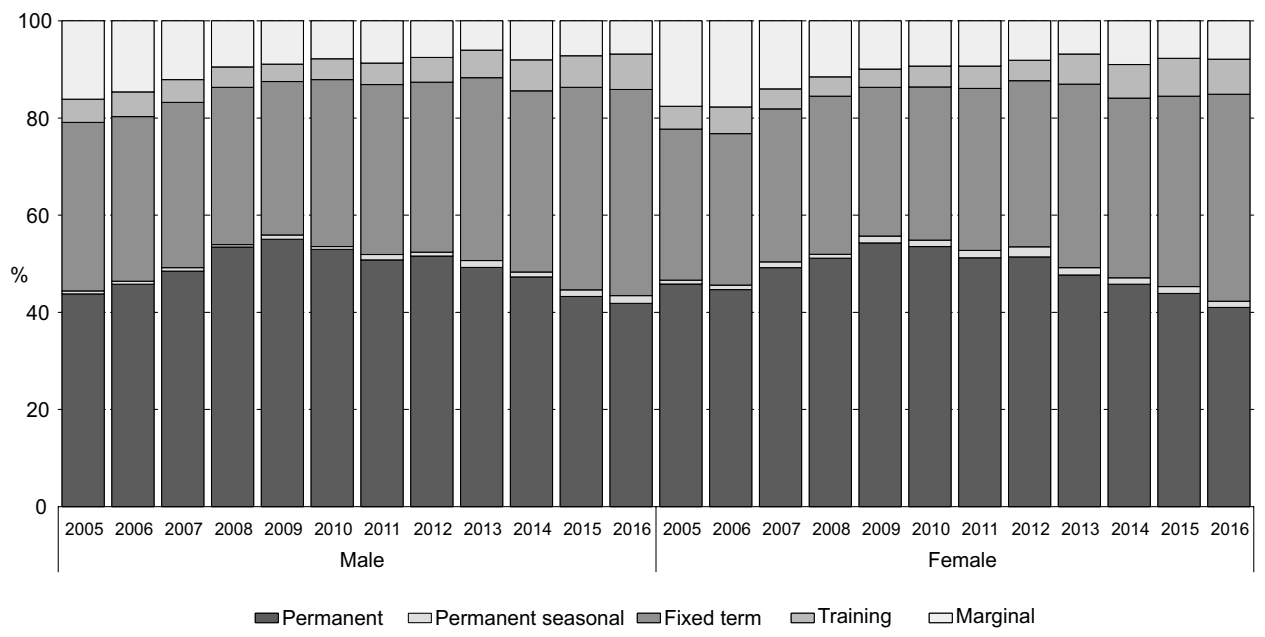

Figure 2 Type of contract by gender 2005-2016 (\%)

Source: Spanish Labor Force Survey (EPA) 2005-2016.

higher in the case of women (17.6\%). However, by 2016, this type of contract affected $7.3 \%$ of young men and women, leading to a trend of over-representation of women, with females accounting for $7.9 \%$, as compared to $6.8 \%$ for males.

As the data suggests, as age increases, the odds of experiencing precarious work contexts decreases for both men and women. On the other hand, it can be seen that, in the analysis by gender, men are more likely to live in precarious situations, doubling the probability of women in the central years of the crisis, and with this probability quadrupling in relation to older men (see Table 3, years 2011 and 2012). As for unmarried youth, their chances of having a precarious job are fluctuating, especially among men, with levels that double or almost double those of married workers. This is even more significant for unmarried young males.

It is also noteworthy that girls between the ages of 16 and 19 years have a more steady probability of precariousness through the analyzed time period. To some extent, this may be a reflection of an extremely fluctuating and uncertain labor market fueled by 2010 and 2012 legal reforms which encouraged temporary hiring, part-time contracts, irregularity of working time, etc. As pointed out in previous research, the impact of the crisis on employment has not been homogeneous, but rather, it has had a greater effect on young people, especially those between 16 and 29: the last to arrive is the first to leave (Rocha and Aragón, 2012).

As for the probability of precariousness among young foreigners, a downward trend is observed, even below the levels of national youth. This is especially the case for women, who in general, are less likely to have precarious jobs as compared to Spanish women. The decrease in the case of males has been very significant, going from a probability of 1.47 in 2005, to 0.65 in 2016. For women, since 2007, they have hovered around one or less (from 1.05 in 2007 to 0.93 in 2016). 
In the case of training level, it is seen that, except in specific cases, both before and at the end of the crisis, the probability of young people having precarious jobs is equal to or lower than that of those young workers who have a higher education; both men and women already have intermediate studies, or primary and lower. As for young people who perform some type of regulated or non-regulated training, it is repeated that structurally, both men and women who do not study are half as likely to have precarious jobs than young people performing some type of training.

Industry has traditionally been the Spanish sector with the least precariousness, both due to its collective agreements, which have a higher level of protection and because it is less affected by temporary elements, as opposed to the service, agriculture and construction sectors. For example, in 2005, industry and construction workers were less prone to precariousness than those in the service and agriculture sectors (reference value). However, major differences can be observed based on gender. Therefore, in the case of agriculture, in 2005, work by females was less precarious than in other sectors. However, over the past 20 years, the evolution of the labor market has led to industry no longer being a guarantee against precariousness, especially for women, whereas jobs in agriculture are less likely to be precarious. This is mainly due, on one hand, to the de-seasonalization of agricultural production and, on the other hand, to the introduction of measures of flexibility in industrial production, especially unfavorable for young people entering the sector. In summary, the precarization of the service sector has been consolidated (a fact that is remarkably serious considering that 7 out of 10 jobs in the Spanish labor market form part of that sector) along with the ongoing precarization of the manufacturing sector.

As for gender differences, with few exceptions, women are less protected from precariousness in all sectors. Precariousness in the service sector is especially noteworthy, where lack of protection against it doubles or triples for women as compared to men.

In the case of occupations, although there are nine different sets of groups, for ease of analysis, the difference will be presented by comparing the second highest occupational group (technical, scientific and intellectual professionals) with the lowest ranking (elementary occupations). In the case of women, the act of occupying a position as a scientific technician protects more against precariousness than in the case of men, to the extent that for men, this type of work is even more prone to precariousness than in the case of unskilled workers.

Regarding the differences between hours worked and hours agreed in the contract, less precarious jobs are those in which the worker works up to ten hours more than the hours included in the contract. There are hardly any differences based on gender and the distinctions are quite stable during the analyzed period. These data are in accordance with the volume of informal economy typical of the Spanish economy.

In the case of contract duration, both for men and women, young people with less time working in the company are much more likely to have precarious jobs. Thus, for example, in 2016 women who have been in the company for less than six months were up to nine times more likely to have a precarious job as compared to 
those working for the company for more than three years, reaching a figure of 8.17 for men. These figures were 5.53 and 7.08, respectively in 2005 .

The hierarchical segmentation (figure 3 ) shows that the percentage of precarious jobs has increased in general terms during the analyzed period, despite improvement in the macroeconomic indicators of the Spanish economy. When performing an analysis by gender, a greater precariousness is detected in women, suggesting that the gender gap has grown. The intensity of precariousness is greater in the case of women, to the extent that activity and occupation rates are lower than those of men. Regardless of the fluctuations of the economic cycle, precariousness in youth employment is embedded as a structural phenomenon in Spain's economy.

In the case of women, the consolidation of a profile where precarious jobs are agglutinated is observed. The first level predictor node is contract duration, so precariousness profiles are concentrated in contracts under 18 months. The profile of precariousness is stressed mainly in the case of young women who are simultaneously working and being trained. Precariousness profiles evolve so that precariousness is not only limited to contracts of less than six months, but also, as of 2010, precariousness profiles are found in contracts from 7 to 18 months, especially in the case of those under the age of 25, and with particular incidence among young women aged 16 to 19. Thus, in 2011, 2015 and 2016, 100\% of the young women who studied, worked for a period between 7 and 18 months and held a precarious job.

In the case of short-term contracts, over the last three years analyzed, the precariousness of young women who study and have a precarious contract was consolidated as a precarious profile; especially in industry and the service sector. Thus, since 2014 at least three quarters of the jobs of young people in these sectors were precarious. Especially relevant is the case of young women who study and work in the services sector, since they have a higher predicted probability of at least $98.4 \%$ since that same year, which is especially serious considering that the service sector generates more than three-quarters of the country's total jobs.

In the case of men, as with the case of women, there is also a consolidation of precariousness profiles (with the parenthesis of the initial years of the crisis between 2008 and 2011 where precariousness has a more transversal profile) affecting a greater diversity of profiles. In addition, as occurred with women, precarious workers are characterized by contract duration (less than 18 months), studying while working, being under the age of 24 and working in the service sector. Therefore, in both genders, there is a recurrent profile of young people who study, have a contract of less than 18 months and work in the service sector, with data that are practically identical to those of women, since 2014 those nodes predict at least $97.9 \%$ of all precarious jobs.

The data are in line with those shown in the logistic regression analysis, where the predictive nature of training, age and duration of the contract variables was significant. 


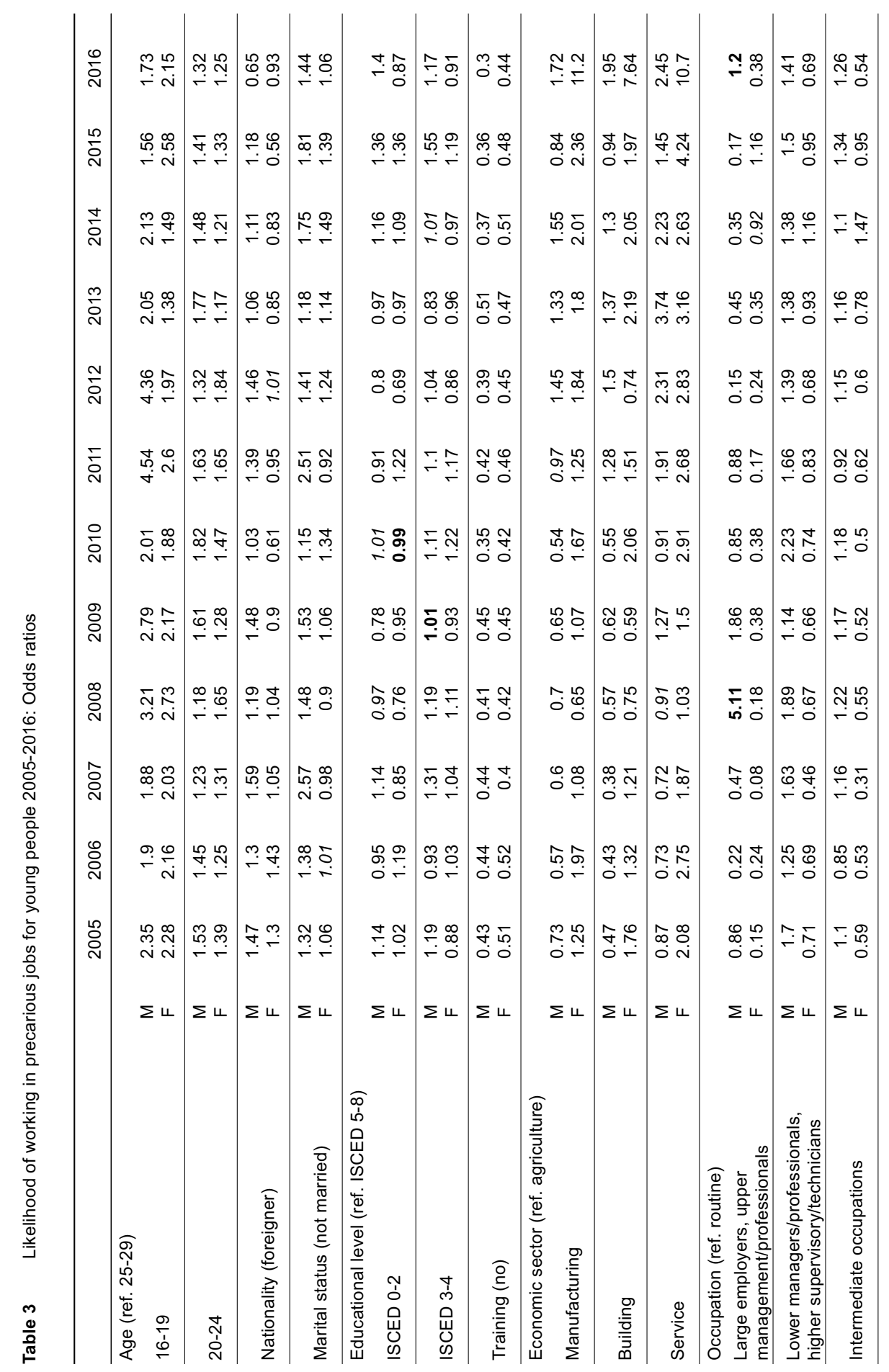




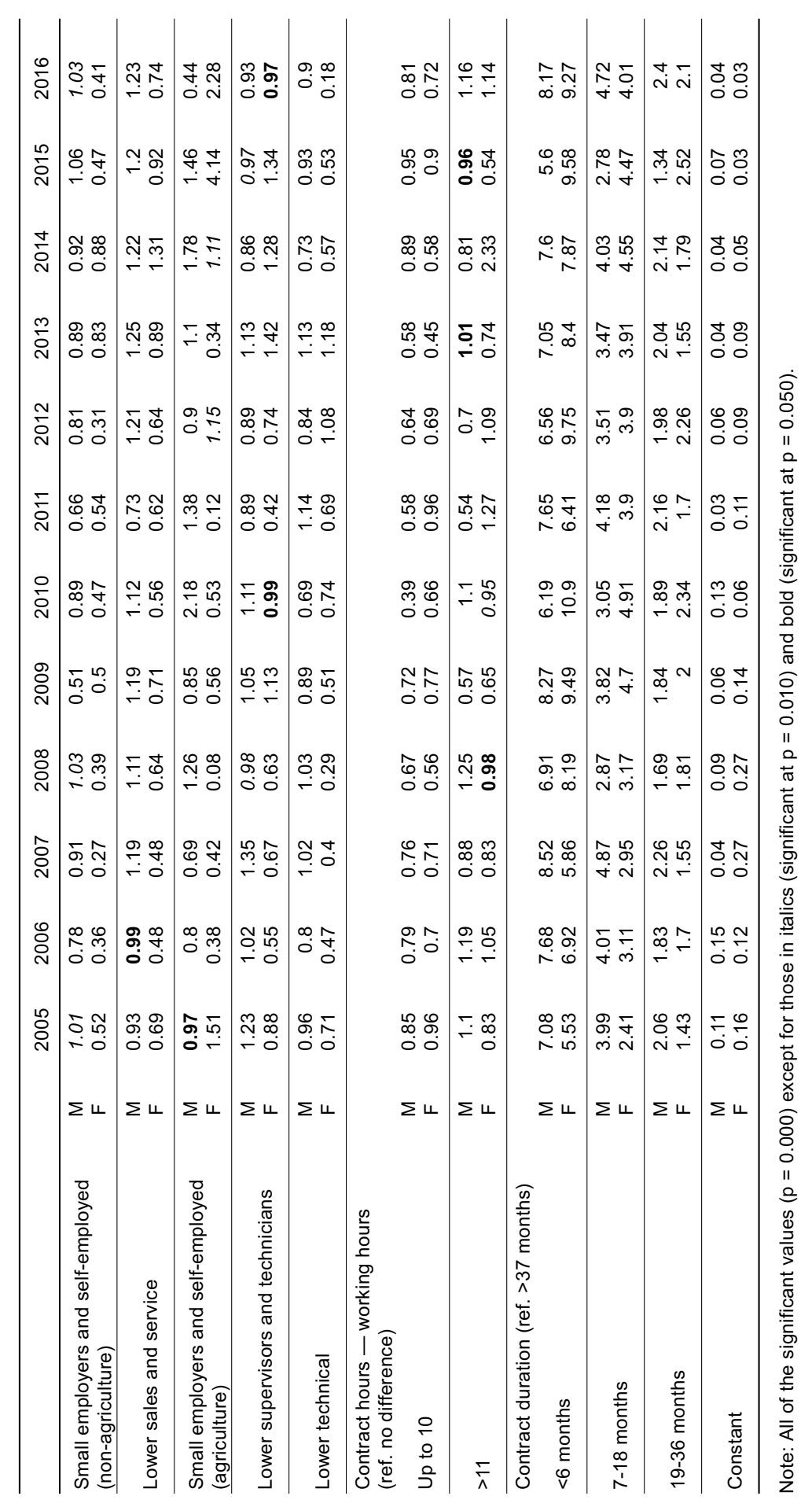




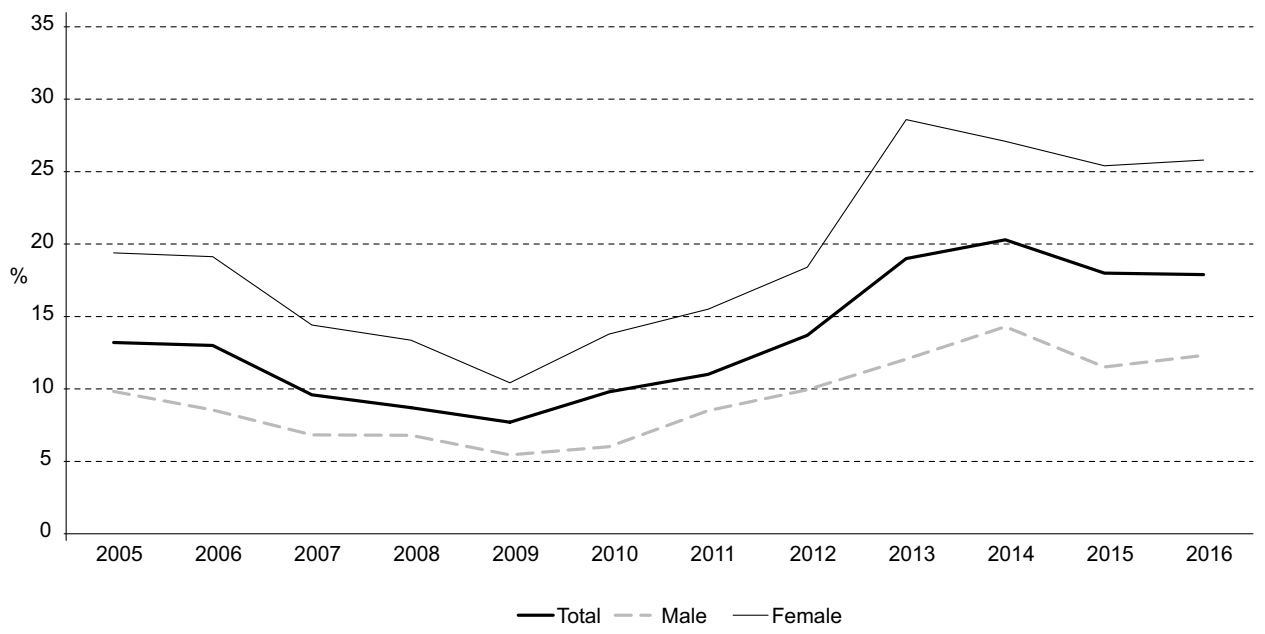

Figure 3 Precarious jobs by gender 2005-2016 (\%): Top-down nodes

Source: Spanish Labor Force Survey (EPA) 2005-2016

\section{Conclusions}

Previous research align with the findings of this article (Yeung and Yang, 2020; Matias and Carmo, 2018; Elder and Kring, 2016; Kretsos and Livanos, 2016; Rocha and Aragón, 2012). In addition, the methodology has been used in a similar manner (Kretsos and Livanos, 2016), proving to be a robust way to measure the impact of labor characteristics in precarization. Young people (16 to 29 years of age) currently working in countries like Spain, work in informal, unstable, precarious and poorly paid jobs (Yeung and Yang, 2020). The results reveal a significant influence of gender in the prediction of precariousness. This is a constant trend throughout the eleven years analyzed, even more stressed in the moments of economic recovery, that is, over the last years. The gap in precariousness increases from 9.6 to 13.5 points between 2005 and 2016. The only reduction in differences is observed in years of economic recession, reaching a minimum of 5 percentage points in 2009 due to the general decline in recruitment that fundamentally affects jobs with less protection and, therefore, more precarious ones.

Two conclusions may be drawn: On the one hand, the ineffectiveness of employment policies aimed at reducing precarious employment, which are ineffective even in times of economic boom. On the other hand, the structural gender inequality in the Spanish labor market, which is apparent and persistent.

The most common precarious job is the one held by young women (aged 16 to 19), regardless of their qualifications and who continue to undergo some kind of training, usually, in a short-term contract (six months or shorter), in the services sector (mostly personal, small retail services), and working 11 or more hours beyond those of the contract. 
In line with previous empirical and theoretical contributions, the idea of greater intensity of precariousness for women in the labor market is reinforced. The intersection of inequalities in the Spanish labor market results in incorporation to the labor market mediated by a system of local preferences and demand "lines" that relegate women and other groups to the most precarious jobs, especially for young women.

A significant and growing proportion of youth and young adults are being socially excluded from participation in productive life, and their trajectories to adulthood are cut short.

Precariousness is not a temporary state that young people must experience during their first stage of access to work, since this period is gradually extending, surpassing the stages of youth. The Government must take measures to control the forms of contracting, controlling excess overtime, and forcing companies and contractors to clarify job offers. There is also a need for greater regulation of precarious contracts and greater control of the same, with the goal of reducing part of the shadow economy that characterizes Spain's economy. Young people should be offered more training, internships and scholarships to ease the school-work transition, especially in the case of women. However, these measures will be useless unless more forceful measures are taken in two fronts, changing the Spanish production model, orienting it towards the production of value-added goods and services, as well as greater investment in improving its human capital, raising the standards of the educational society.

Sociology must not ignore the gender perspective when analyzing the emergence of a precariat, so as to avoid some of the mistakes made by the sociological theories, especially neo-Marxist ones, which homogenously analyzed the overall working class. Similarly, the intensity of the phenomenon in territorial dynamics must not be underestimated, since specialized literature reveals a greater extension of precariousness in southern European countries. Future lines of research should consider this southern perspective. Finally, administrations and policy makers must reconsider a comprehensive strategy to confront precariousness, seeking ways to avoid it that are mainly based on policies of positive discrimination for the most vulnerable groups, beyond the (effective) regulation of the labor market.

\section{References}

Adams, Z., and S. Deakin (2014), “Institutional solutions to precariousness and inequality in labour markets", British Journal of Industrial Relations, 52 (4), pp. 779-809.

Alberio, M. (2011), The Working Poor Condition in Europe. A Focus on Italy, Montréal, Cahiers du CRISES, Collection Études Théoriques, ET1108.

Alcañiz, M., and R. Monteiro (2016), “She-austerity: women's precariousness and labor inequality in Southern Europe", Convergencia - Revista de Ciencias Sociales, 72, pp. 39-68. 
Alonso-Borrego, C., and J. E. Galdón (2007), La Protección al Empleo en España. Evolución Y Consecuencias, Madrid, Ministerio de Industria, Turismo y Comercio.

Arriba, A. (2009), “Rentas mínimas de inserción de las Comunidades Autónomas: una visión conjunta de su evolución y alcance", Gestión y Análisis de Políticas Públicas, 2, pp. 81-99. Available at https://www.redalyc.org/articulo.oa?id=281521695004 (last access in May 2021) .

Artazcoz, L., I. Cortès, F. G. Benavides, V. Escribà-Agüir, X. Bartoll, H. Vargas, and C. Borrell (2016), "Long working hours and health in Europe: gender and welfare state differences in a context of economic crisis", Health $\mathcal{E}$ Place, 40, pp. 161-168. DOI: http://dx.doi.org/10.1016/j.healthplace.2016.06.004.

Asçi, M. S. (2018), "Precarious work, precariat and excluded personnel”, Journal of Industrial Policy and Technology Management, 1 (2), pp. 99-114.

Ballester, M. A. (2012), “De cómo la reforma operada por el RD Ley 3/2012 ha degradado el drecho fundamental a la conciliación de responsabilidades", Revista de Derecho Social, 57, pp. 99-114.

Belzunegui, A. G. (2012), La Socialización de la Pobreza en España. Género, Edad y Trabajo en los Riesgos Frente a la Pobreza, Barcelona, Icaria.

Bernardi, F., and M. Ares (2017), “Education as the (not so) great equalizer: new evidence based on a parental fixed effect analysis for Spain", EUI Working Paper, SPS 2017/6.

Bettio, F., M. Corsi, C. D'Ippoliti, A. Lyberaki, M. S. Lodovici, and A. Verashchagina (2012), The Impact of the Economic Crisis on the Situation of Women and Men and on Gender Equality Policies, Brussels, European Commission. Available at: https://op.europa.eu/en/publication-detail/-/publication/4a10e8f6-d6d6-417e-aef5-4 b873d1a4d66.

Blanco, A. B., I. A. Muñoz, E. C. Molina, C. R. de Miguel, and E. E. Casas (2015), "Aplicaciones de la segmentación jerárquica en medición y evaluación de programas educativos: ejemplos con un programa de educación financiera", Educación XXI - Revista de la Facultad de Educación, 20 (2), pp. 235-257.

Cebrián, I., and G. Moreno (2007), “El empleo femenino en el mercado de trabajo en España", Temas Labourales - Revista Andaluza de Trabajo y Bienestar Social, 91, pp. 35-56.

Craig, L., B. Churchill, and M. Wong (2018), "Youth, recession, and downward gender convergence: young people's employment, education, and homemaking in Finland, Spain, Taiwan, and the United States 2000-2013", Social Politics. International Studies in Gender, State E Society, Summer 2018, pp. 1-28.

Dahrendorf, R. (2005), En Busca de Un Nuevo Orden. Una Política de la Libertad para el Siglo $X X I$, Barcelona, Paidós.

do Carmo, R. M., and A. R. Matias (2019), Retratos da Precariedade. Quotidianos e Aspirações dos Trabalhadores Jovens, Lisbon, Tinta da China.

Elder, S., and S. Kring (2016), "Young and female - a double strike? Gender analysis of school-to-work transition surveys in 32 developing countries", Geneva, Internartional Labor Office.

Erikson, R., M. Savage, F. Devine, N. Cunningham, M. Taylor, Y. Li, ... and A. Miles (2013), “A new model of social class? Findings from the BBC's Great British Class Survey Experiment", Sociology, 47 (2), pp. 219-250. Availabe at https://doi.org/10.1177/0038038513481128. 
Escobar, R. M. (2007), “El análisis de segmentación: técnica y aplicaciones de los árboles de clasificación”, Revista Internacional de Sociología, 67 (3), pp. 736-741.

Fullerton, A. S., D. L. Robertson, and J. C. Dixon (2011), “Reexamining the relationship between flexibility and insecurity", in Comparing European Workers, Part A, Bingley, UK, Emerald Group Publishing Limited, pp. 9-41.

Gálvez, Li, and P. Rodríguez (2013), “El empleo de las mujeres en la España democrática y el impacto de la Gran Recesión", Áreas - Revista Internacional de Ciencias Sociales, 32, pp. 105-123.

Girón, A., and E. Correa (2016), “Post-crisis gender gaps: women workers and employment precariousness", Journal of Economic Issues, 50 (2), pp. 471-477. DOI: $10.1080 / 00213624.2016 .1179049$

Golsch, K. (2003), “Employment flexibility in Spain and its impact on transitions to adulthood", Work, Employment and Society, 17 (4), pp. 691-718.

Greer, I. (2016), "Welfare reform, precarity and the re-commodification of labour", Work, Employment and Society, 30 (1), pp. 162-173.

Grimshaw, D., C. Fagan, G. Hebson, and I. Tavora (2017), “A new labour market segmentation approach for analysing inequalities: introduction and overview", in D. Grimshaw, C. Fagan, G. Hebson, and I. Tavora, Making Work More Equal, Manchester, Manchester University Press.

Han, W.-J., C. J. Ruhm, J. Waldfogel, and E. Washbrook (2008), “The timing of mothers' employment after childbirth", Monthly Labour Review, 131 (6), pp. 15-27.

Jongbloed, J., and A. Pullman (2016), “Well-being in the Welfare State: the redistributive capacity of education", European Journal of Education, 51 (4), pp. 564-586.

Kalleberg, A. L. (2009), "Precarious work, insecure workers: employment relations in transition", American Sociological Review, 74 (1), pp. 1-22. Available at: http://www.jstor.org/stable/27736045 (last access in May 2021).

Klein, B. W., and P. L. Rones (1989), "A profile of the working poor", Monthly Labour Review, 112 (10), pp. 3-13.

Kretsos, L., and I. Livanos (2016), “The extent and determinants of precarious employment in Europe", International Journal of Manpower, 37 (1), pp. 25-43.

Kuster-Boluda, I., J. Aldas-Manzano, M. Rodríguez-Santos, and N. Vila (2010), "Cross-cultural differences in purchasing decisions among European youth", Innovar, 20 (37), pp. 163-178.

Lohmann, H. (2009), “Welfare states, labour market institutions and the working poor: a comparative analysis of 20 European countries", European Sociological Review, 25 (4), pp. 489-504.

Lombardo, E., and M. León (2014), "Políticas de igualdad de género y sociales en España: origen, desarrollo y desmantelamiento en un contexto de crisis económica", Investigaciones Feministas, 5, pp. 13-35.

Marrero, J. R., P. Rodríguez, and J. M. Ramos-Henríquez (2016), “La flexibilidad laboral en el sector turístico: un análisis a partir de las ofertas de empleo", Estudios y Perspectivas en Turismo, 25 (2), pp. 143-163.

Matias, A. R., and R. M. do Carmo (2018), “Precariedade e desigualdade: números e considerações sobre uma relação perversa", in Renato Miguel do Carmo, João Sebastião, Joana Azevedo, Susana da Cruz Martins, and António Firmino da Costa 
(Eds.), Desigualdades Sociais. Portugal e a Europa, Lisboa, Mundos Sociais, pp. 81-91. McKay, S., S. Jefferys, A. Paraksevopoulou, and J. Keles (2012), “Study on precarious work and social rights", working paper, Working Lives Research Institute, London Metropolitan University.

Mosoetsa, J. Stillerman, and C. Tilly (2016), “Precarious labor, south and north: an introduction", Franco Barchiesi and Kate Brown (eds.), International Labor and Working-Class History, 89, pp. 5-19. Doi: 10.1017/S0147547916000028.

Munck, R. (2013), “The precariat: a view from the South”, Third World Quarterly, 34 (5), pp. 747-762.

Odriozola, L. A., and B. E. Peña (2016), “Segregación ocupacional por género y nacionalidad en el mercado laboural español / Gender and nationality based occupational segregation in the Spanish labour market", Reis - Revista Española de Investigaciones Sociológicas, 156, pp. 3-20.

Ortiz, L. (2010), “Not the right job, but a secure one: over-education and temporary employment in France, Italy and Spain", Work, Employment and Society, 24 (1), pp. $47-64$.

Ortiz, P. (2013), "Cambios en la legislación laboral y contratación temporal en España", Cuadernos de Relaciones Labourales, 31 (1), pp. 141-165.

Peña-Boquete, Y. (2014), "Have the economic crises reduced the gender gap on the Spanish labour market?", Revue de l'OFCE, 2, pp. 277-302.

Puig-Barrachina, V., C. Vanroelen, A. Vives, J. M. Martínez, C. Muntaner, K. Levecque, ... and F. Louckx (2014), "Measuring employment precariousness in the European Working Conditions Survey: the social distribution in Europe", Work, 49 (1), pp. 143-161.

Rocha, F., and J. Aragón (2012), “La crisis económica y sus efectos sobre el empleo en España", Gaceta Sindical, 19, pp. 69-90.

Román, M. V., and J. P. Lévy (2003), “Clasificación y segmentación jerárquica”, in P. Lévy and J. Varela, Análisis Multivariable para las Ciencias Sociales, Madrid, Pearson Educación, pp. 567-630.

Rubery, J., M. Smith, and C. Fagan (1999), Women's Employment in Europe. Trends and Prospects, London, Routledge.

Rubery, J., and A. Piasna (2016), “Labour market segmentation and the EU reform agenda: developing alternatives to the mainstream", ETUI Research Paper-Working, 10.

Savage, M., F. Devine, N. Cunningham, S. Friedman, D. Laurison, A. Miles, ... and M. Taylor (2015), “On social class, anno 2014”, Sociology, 49 (6), pp. 1011-1030.

Spannagel, D. (2013), “In-work poverty in Europe - extent, structure and causal mechanisms", COPE Project (Combating Poverty in Europe). Available at: http://cope-research.eu/wp-content/uploads/2013/03/In-work_Poverty_in_Europe. pdf (last access in May 2021).

Standing, G. (2013), El Precariado, Barcelona, Pasado y Presente.

Távora, I., and P. Rodríguez-Modroño (2018), “The impact of the crisis and austerity on low educated working women: the cases of Spain and Portugal", Gender, Work E Organization, 25 (6), pp. 621-636. DOI: 10.1111/gwao.12238

Tiwari, M., R. Singh, and N. Vimal (2014), “An empirical study of applications of data mining techniques for predicting student performance in higher education", 
International Journal of Computer Science and Mobile Computing, 2, pp. 53-57.

Torns, M. T., C. Recio, and M. A. Durán (2013), “Género, trabajo y vida económica”, in

C. Díaz and S. Dema, Sociología y Género, Madrid, Tecnos, pp. 153-200.

Torres, J., and L. Gálvez (2010), Desiguales. Mujeres y Hombres en la Crisis Financiera, Barcelona, Icaria.

Yeung, W.-J. J., and Y. Yang (2020), “Labor market uncertainties for youth and young adults: an international perspective", The Annals of the American Academy of Political and Social Science, 688 (1), pp. 7-19. DOI: https://doi.org/10.1177/0002716220913487

Young, M. (2010), “Gender differences in precarious work settings”, Relations Industrielles / Industrial Relations, 65 (1), pp. 74-97.

Juan Carlos Solano Lucas. Departamento de Sociología, Universidad de Murcia, Spain. E-mail: jcsolano@um.es

ORCID: https://orcid.org/0000-0002-2145-4613

Marcos Bote Díaz. Departamento de Sociología, Universidad de Murcia, Spain. E-mail: mbote@um.es

ORCID: https://orcid.org/0000-0002-9178-3105

Juan Antonio Clemente Soler.Departamento de Sociología, Universidad de Murcia, Spain. E-mail: juanantonio.clemente@um.es ORCID: https://orcid.org/0000-0003-2272-6219

José Ángel Martínez López. Departamento de Trabajo Social, Universidad de Murcia, Spain. E-mail: jaml@um.es

ORCID: https://orcid.org/0000-0002-6871-7265

Lola Frutos Balibrea. Departamento de Sociología, Universidad de Murcia, Spain. E-mail: 1fb@um.es

ORCID: https://orcid.org/0000-0002-4328-9954

Receção: 20 de julho de 2020 Aprovação: 23 de novembro de 2020 